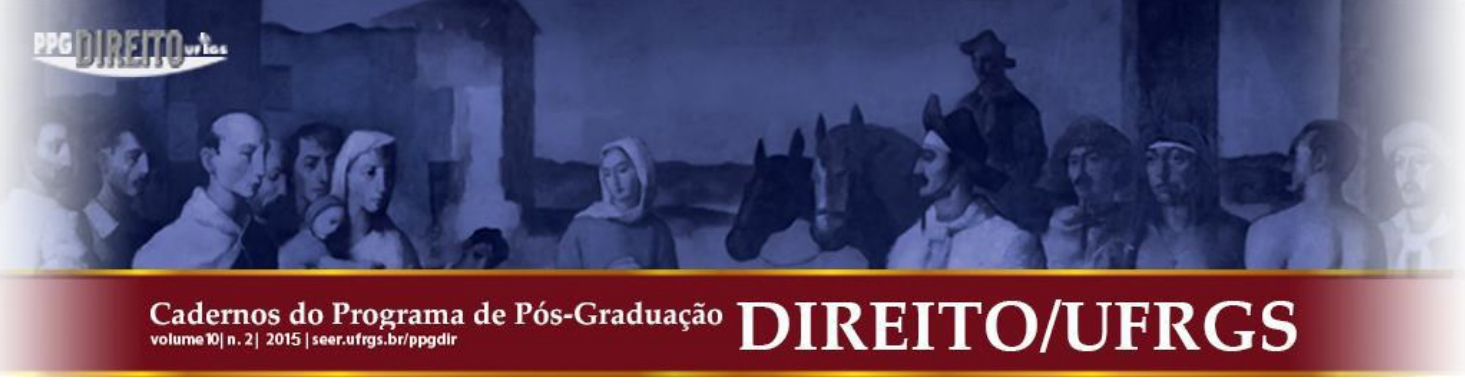

\title{
FALSEAMENTO DA REALIDADE DO DIREITO UNIVERSAL À EDUCAÇÃO
}

\author{
DISTORTION OF THE REALITY OF THE UNIVERSAL RIGHT TO EDUCATION
}

\author{
Anário Dornelles Rocha Junior*
}

\begin{abstract}
RESUMO: A pesquisa compreende analisar os preceitos ideológicos inseridos nos marcos reguladores da educação apresentados sob a forma de direito universal da pessoa e da coletividade humana e o tipo de educação que está sendo aplicado na realidade, alinhados aos pressupostos liberais derivados dos instrumentos jurídicos, sob o fim de auxiliar os estudos acerca do direito, educação, ideologia e, tem, como objetivo: a) compreender o caráter ideológico presente na educação como garantia universal b) verificar os meios utilizados pelo Estado para disseminar sua visão de mundo acerca do direito a educação. Os procedimentos metodológicos utilizados referem-se à pesquisa qualitativa documental, com caráter exploratório, visando identificar os condicionantes legais e seus efeitos na educação, especificamente na prática pedagógica e o conceito de Ideologia, no Direito, no Estado e na Educação. As análises documentais da ideologia presente na educação são evidentes na legislação sob a vertente das Leis de Diretrizes e Bases da Educação, especificamente a lei 9.394/96; e na Constituição Federal de 1988. A base teórica de análises da realidade parte dos pressupostos de ideologia em diferentes autores como Marx (1998), Lowy (2003) e Duarte (2008). Conclui-se que a legislação educacional induz um sentido de educação nos diferentes momentos históricos, privilegiando a ação de controle, coerção, repressão e submissão a ordem estabelecida. Neste sentido o destino do aluno, via ato educativo, está impregnado de certa visão de mundo quanto ao que seja seu direito à educação universal formal/material e o direito do outro, tendo em vista os diferentes sujeitos numa dada sociedade.
\end{abstract}

PALAVRAS-CHAVE: Direito universal à educação. Educação e Ideologia. Legislação e Ideologia. Estado.
ABSTRACT: The research comprises analyzing the ideological precepts inserted in the regulatory frameworks of education presented in the form of universal right of the person and the human collectivity and the kind of education that is being applied in reality, aligned to liberal assumptions derived from legal instruments, in order to assist the studies about law, education, ideology, and has, as its objective: a) to comprehend the ideological character that prevails in the education as universal guarantee; b) to verify the methods used by the State to disseminate its worldview about the right to education. The methodological procedures resorted refer to documental qualitative research with exploratory character, aiming to identify the legal determinants and its effects on education, specifically on the pedagogical practice and the concept of Ideology in Law, State, and Education. The documental analysis of the ideology that prevails in education is evident in the legislation under the aspect of the Laws of Guidelines and Bases of the Education, specifically the law 9394/96; and the Federal Constitution of 1988. The theoretical basis of analysis of the reality is founded on assumptions of ideology of different authors such as Marx (1998), Lowy (2003), and Duarte (2008). It is concluded that the education laws induce a sense of education in different historical moments, favoring the action of control, coercion, repression and submission to the established order. In this sense the fate of the student, through the educational act, is redolent of a certain worldview regarding what is his procedural/substantive right to universal education and the right of the other, considering the different subjects in a particular society.

KEYWORDS: Universal Right to Education. Education and Ideology. Legislation and Ideology. State.

SUMÁRIO: Introdução. 1. Historiando a educação. 1.1. República Velha. 1.2. Década de 1930. 1.3. Ditadura Militar. 1.4. Entre as décadas de 80 e 90. 2. Educação e direito. 2.1. Natureza Jurídica da Educação. 2.2. Remédios constitucionais. 2.3. Educação e a Constituição Federal. 3. Educação/ideologia/direito. Considerações Finais. Referências.

\section{INTRODUÇÃO}

O presente artigo possui a finalidade de estudar a ideologia do direito a educação como direito de todos. Analisando a educação brasileira a partir de cortes históricos, sob a vertente das Constituições e Leis de Diretrizes e Bases da Educação.

\footnotetext{
* Graduado em Direito pela Pontifícia Universidade Federal de Goiás (PUCGO). Licenciado em Educação Física pela Universidade Federal de Goiás (UFG). Especialista em Direito Público pela Universidade para o Desenvolvimento do Estado e da Região do Pantanal (UNIDERP). Mestrando em Educação pela Universidade Federal de Uberlândia (UFU).
} 


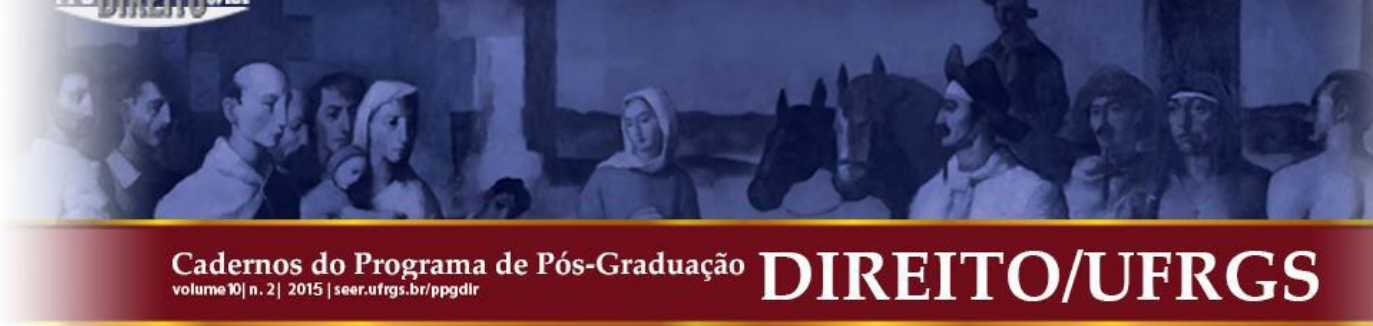

E ainda, demonstra:

\begin{abstract}
Não existe uma história pura da ideologia, da filosofia da religião ou da ciência social, essas histórias têm que ser vistas como elementos de uma totalidade e é só em relação a sua totalidade social, com o conjunto de vida econômica, social e política que se pode entender o significado das informações e das mudanças que vão se dando, por exemplo no terreno das ideologias. (LOWY, 2003, p. 16)
\end{abstract}

Cabe salientar que a objetividade do direito presente no campo educacional e as características ideológicas que estão por trás do discurso da educação e do direito, em face do dever do estado na execução do ensino a todos, enseja elementos necessários para compreender, discutir, diagnosticar, interrogar, intervir e superar as problemáticas do tipo de educação que a norma estabelece atualmente. Ao analisar a ideologia do Direito (Campo teórico que normatiza o direito, dever, e as garantias individuais e sociais) presente na educação brasileira, pode se observar nos distintos momentos sociais da realidade do Brasil que o pensamento liberal serve de pano de fundo nos diferentes documentos legais para imprimir valores, comportamentos e assegurar direitos e que esta orientação está presente em vários instrumentos jurídicos, dentre os mais conhecidos estão a Constituição Federal de 1988 e a atual Lei de Diretrizes e Bases da Educação.

É nesse entendimento que o presente artigo será direcionado, tendo como objetivo compreender o caráter ideológico presente no direito educação como garantia universal, a partir do discurso idealizado acerca do real por meio do contexto histórico e a relacional ideologia, direito e educação. Já a metodologia utilizada é a pesquisa qualitativa, com caráter exploratório, partindo do levantamento bibliográfico, a respeito do caráter ideológico a respeito da educação como direito universal.

\title{
1 HISTORIANDO A EDUCAÇÃO
}

\subsection{República Velha}

A escola pública é produto da ordem burguesa e sua iniciação está ligada à ascensão da burguesia e ao processo de industrialização por ela conduzido, que demandava grande quantidade de mão-de-obra. Nesse sentido, produzindo a necessidade de realizar a instrumentalização das massas para o labor fabril, demonstrando os mesmos com ideais burgueses, falseados de universalidade, democracia e igualdade. 


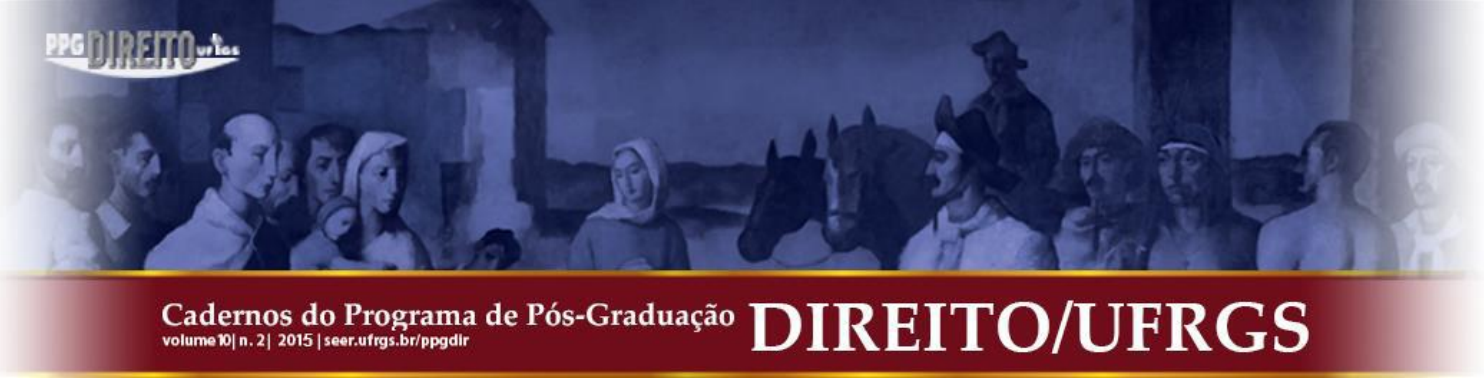

A organização desses grupos configurou a base do modelo seriado que seria disseminado em toda a educação brasileira. Segundo Saviani (2008), esse modelo proporcionava a homogeneização do ensino e possibilitava um maior rendimento escolar, contudo, a super exigência no ensino, já acarretava altos índices de repetência. "No fundo, era uma escola mais eficiente para o objetivo de seleção e formação das elites. A questão da educação das massas populares ainda não se colocava". (SAVIANI, 2008, p. 175).

Contudo, por mais que as reformas realizadas em São Paulo fossem amplamente criticadas, elas de fato representavam um esforço de possibilitar a educação primária a todos. Como o Estado não tinha condições de possibilitar uma instrução básica de quatro anos para toda população, “a Reforma Sampaio Dória institui uma escola primária cuja primeira etapa, com duração de dois anos, seria gratuita e obrigatória para todos” (SAVIANI, 2008, p. 175). Apesar de se ter recebido várias críticas e não ter sido plenamente implantado, a reforma abriu portas para várias alterações na educação pública como:

ampliação da rede de escolas; o aparelhamento técnico-administrativo; a melhoria das condições de funcionamento; a reformulação curricular; o início da profissionalização do magistério; a reorientação das práticas de ensino; e, mais para o final da década, a penetração do ideário escolanovista (SAVIANI, 2008, p.177)

Entrementes, a educação da população sofre interferências no âmbito econômico, mascarando o meio escolar como democrático. E assim, elementos como ler, escrever são requisito basilares para a produtividade laboral, conforme ressalta Nagle (1976, p. 115):

no campo da escolarização, isso se traduziu sob a forma de preocupação com o ensino técnico-profissional, capaz de formar mão-de-obra nacional e fazer, da civilização brasileira, uma civilização eminentemente 'prática', como 'práticas' eram as mais modernas e avançadas civilizações do mundo contemporâneo.

Assim, ainda segundo o autor, é estabelecida a relação entre a capacidade produtiva e a cultura da técnica como novo núcleo de preocupação educacional, principalmente pela competição com a mão-de-obra estrangeira devido o alto fluxo imigratório no período.

Diante dessas transformações sociais, temos a década de vinte marcada pela "efervescência ideológica" e "inquietação social" resultando no surgimento do "inusitado entusiasmo pela escolarização e de marcante otimismo pedagógico" (NAGLE, 1976, p. 99) que conduzia a crença de que a educação escolar iria possibilitar o progresso nacional, "reformar a sociedade pela reforma do homem", colocando o Brasil "no caminho das grandes 


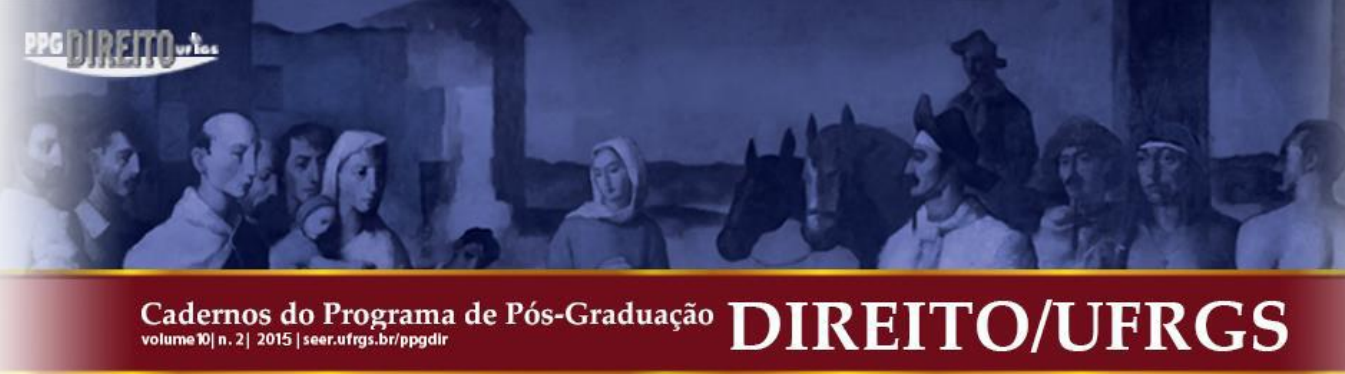

nações do mundo" (NAGLE, 1976, p. 100). Nesse período é que nos deparamos também com a inserção do escolanovismo como formulação educacional que indicaria a "verdadeira formação do novo homem brasileiro".

\subsection{Década de 1930}

Várias transformações estavam ocorrendo no país, e a inserção da Escola Nova no contexto educacional no Brasil dá um novo sentido. Apesar que suas ideias já estavam sendo implantadas e desenvolvidas no período da República Velha. Segundo Nagle (1976), até a década de 20, o país não possuía condições sociais e pedagógicas para desenvolver um novo modelo escolar, além de, naquele período, não haver insatisfação com o modelo pedagógico adotado. Era necessário ampliar a instrução primária com o intuito de conter o analfabetismo, porém não se menciona a renovação de concepções pedagógicas. Nesse período, a preocupação central estava voltada para a formação cívica e moral, apoiados nos princípios da nacionalidade.

É a partir da década de vinte que os ideais de renovação e reforma da educação passam a ser discutidas. "No Brasil praticamente existiu sincronia entre a propagação das ideias e as mudanças institucionais comprometidas com essa nova corrente" (NAGLE, 1976, p. 241).

O escolanovismo representava nesse período o liberalismo no campo educacional, "representa uma alteração profunda na compreensão do processo de aprendizagem" (NAGLE, 1976, p. 243) que refutam, definitivamente, os fundamentos da escola tradicional. Há uma necessidade de se romper de vez com o modelo tradicional de educação, que na época era direcionado pela Igreja Católica. No período de 1930 à meados do fím da década de 1940, o movimento da Escola Nova irá disputar espaço com a Igreja, sendo que, após esse período, o escolanovismo cria hegemonia no campo educacional, influenciando inclusive a educação conduzida pela Igreja Católica.

Após a Revolução de 30, percebe-se uma ligação com a religião católica nas questões políticas e concomitantemente no âmbito educacional. Saviani aduz vários efeitos na relacional Estado e Igreja (2008):

A visão comum compartilhava conceitos como o primado da autoridade; a concepção verticalizada de sociedade em que cabia a uma elite moralizante conduzir 


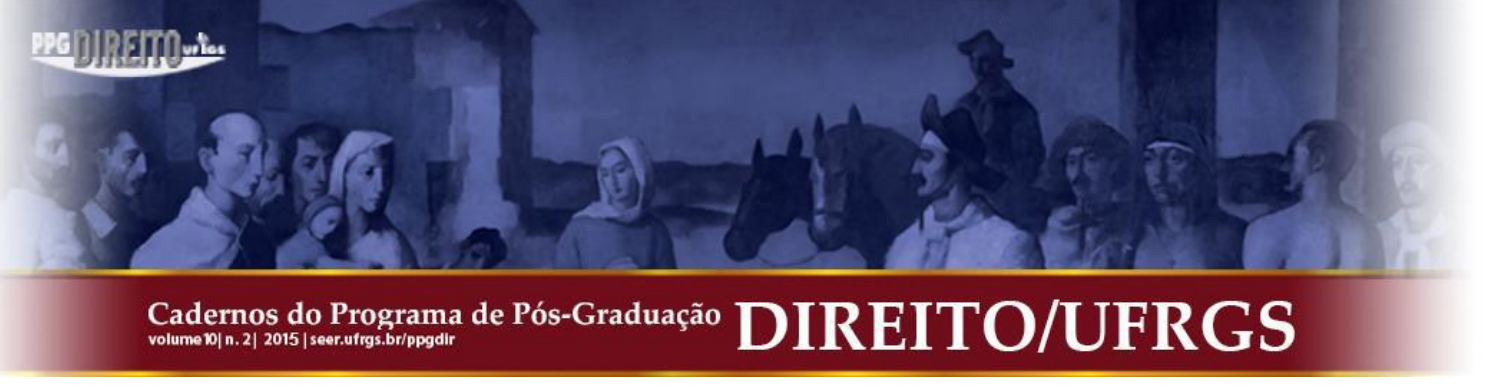

o povo dócil; a rejeição da democracia liberal, diagnosticada como enferma; a aliança entre a conservação tradicionalista dos católicos e a modernização conservadora dos governantes; a tutela do povo; o centralismo e intervencionismo das autoridades eclesiásticas e estatais; o anticomunismo exacerbado; a defesa da ordem e da segurança; defesa do corporativismo como antídoto ao bolchevismo (SAVIANI, 2008, p. 265).

Motta (1997, p. 117) aduz que a Constituição de 1937 apresenta um caráter democrático, tendo em vista que trata a educação como direito de todos; dever da família e poderes públicos em ministrar; o ensino primário gratuito e de frequência obrigatória extensiva aos adultos e a gratuidade do ensino.

Após algumas manifestações, surge o movimento escola nova, o qual propôs a laicidade, gratuidade e responsabilidade pública em educação (RIBEIRO, 1978). Assim, a educação não é interesse de classes e, sim, uma responsabilidade do Estado:

A escola pública, gratuita e leiga era vista pelos educadores como a situação ideal,
justamente com vistas ao atendimento das aspirações individuais e sociais, o que
equivale ao contrário de qualquer imposição orientadora, quer seja de ordem
religiosa, quer seja de ordem política. Ao indivíduo caberia fazer a opção.
(RIBEIRO, 1978, p. 112)

Segundo Nagle (1976), o movimento da escola nova se fundamenta em um novo ideário de criança, onde o respeito a ela, aos seus interesses e necessidades individuais que estão ligadas ao desenvolvimento natural da criança, devem ser valorizados. Ao professor, cabe apenas fornecer meios para que a criança se desenvolva, sozinha. Da mesma forma, a escolha de conteúdos deve estar relacionada aos interesses da criança e não fora dela. "O que importa agora é a realização das potencialidades contidas na personalidade integral da criança, em cada etapa do seu desenvolvimento" (p. 249).

A Escola Nova obteve mais espaço durante os anos, segundo salienta Saviani "A predominância da pedagogia nova já pode ser detectada na comissão constituída em 1947 para elaborar o projeto da LDB, composta com uma maioria de membros pertencentes a essa corrente pedagógica" (p. 300).

A partir da década de 50, com o governo $\mathrm{JK}$, temos uma intensificação da movimentação popular. "A ideia-força do desenvolvimento nacional aliada à política populista incitava à mobilização das massas" (SAVIANI, p. 316). A educação popular vai assumindo novas formas, onde o povo se posiciona no sentido de politização e conscientização da população. Essa década também é marcada pelo espírito desenvolvimentista. 


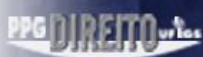

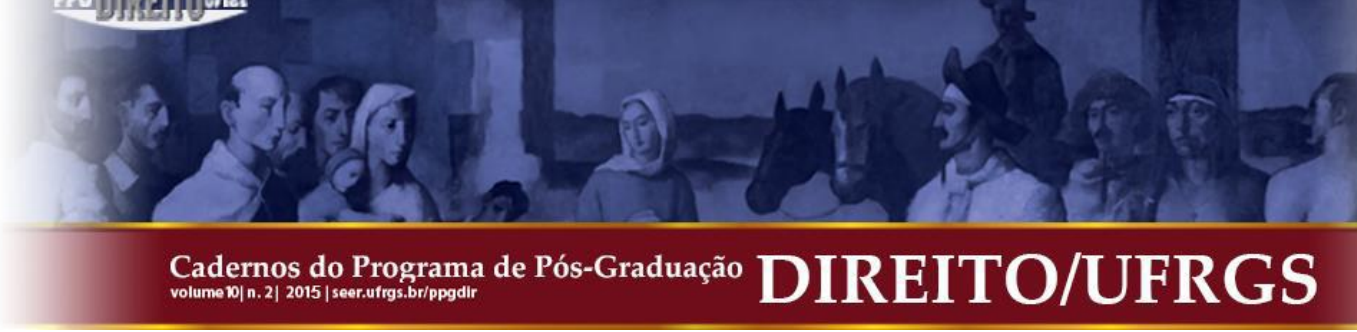

democrática, amparando-se na humanização do indivíduo por meio dos direitos aos cidadãos, especialmente ao direito da educação de qualidade.

Nesse sentido Zaindan (2003, p. 144) dispõe:

O mundo atual tem exigido uma formação mais global dos sujeitos sociais. Escola é cada vez mais sinônimo de educação. Isso significa que além do papel de incorporação e transmissão dos conhecimentos científicos e das habilidades consideradas essenciais pela sociedade, a escola está se colocando a tarefa de formação mais ampla para a cidadania, do aluno como sujeito social.

Buscando efetivar os interesses democráticos e assegurar os direitos de cada cidadão é promulgada a Constituição em 1988 e a edição da nova Lei de Diretrizes e Bases da Educação Nacional, que passou a ser chamada de Lei 9.394/96. Essas normas visaram a democratizar o ensino significativo para os movimentos sociais em garantir o acesso, permanência e qualidade da educação a todos e obrigação do Estado em cumprir tal ideário político-social.

Nessa direção Silva (2010, p. 51), percebe a democratização do ensino, buscou constituir uma identidade pautada pela liberdade política e participação do povo. No entanto, atenta-se que essa participação surge algumas ideologias, especialmente em face de pedagogias educacionais.

Assim, Saviani (2007, p. 11) salienta acerca da democracia e educação:

A expressão "transição democrática" é ambígua do ponto de vista da linguagem porque pode significar tanto "transição para a democracia" como uma "transição que é feita democraticamente". Neste segundo caso não se especifica o ponto de partida nem o ponto de chegada da transição. Ora, transição significa passagem, movimento de um ponto a outro. Pergunta-se então: transição (democrática) de que para quê?

E ainda, Saviani relata que na década de 1980 emerge como proposta contrahegemônica a concepção pedagógica histórico-crítica. Nessa formulação a educação é entendida como mediação no seio da prática social global. A prática social se põe, portanto, como o ponto de partida e o ponto de chegada da prática educativa. Daí decorre um método pedagógico que parte da prática social onde professor e aluno se encontram igualmente inseridos ocupando, porém posições distintas, condições para que travem uma relação fecunda na compreensão e encaminhamento da solução dos problemas postos pela prática social, cabendo aos momentos intermediários do método identificar as questões suscitadas pela prática social (problematização), dispor os instrumentos teóricos e práticos para a 


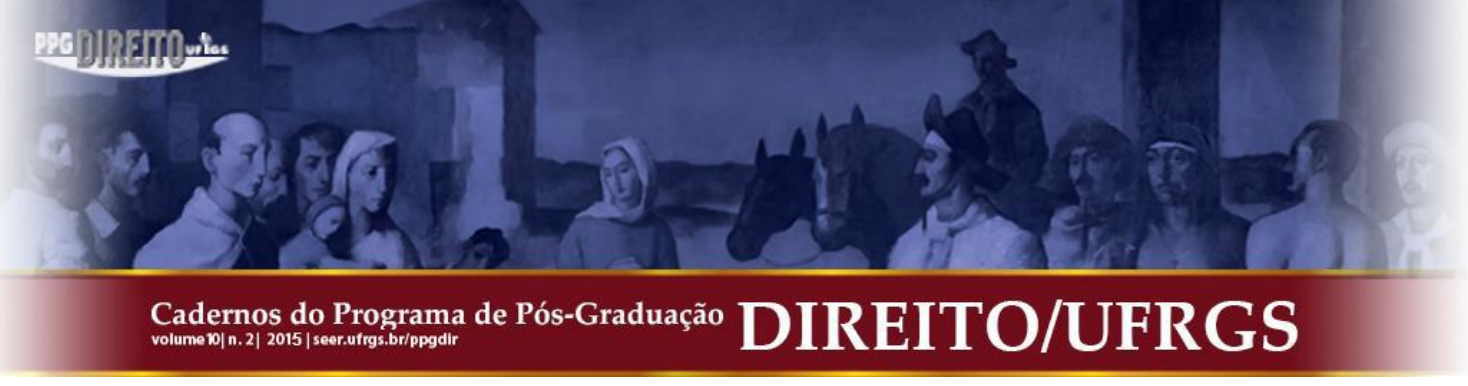

compreensão e solução (instrumentalização) e viabilizar sua incorporação como elementos integrantes da própria vida dos alunos.

A Lei de diretrizes e bases da educação, ou seja, a lei 9.934/96, delimitou acerca do campo educacional de forma totalizante, a presente norma iniciou-se com as propostas feitas na Conferência em 1987, pela "Carta de Goiânia". E assim, estabeleceu-se parâmetros, princípios, e o rumos acerca da educação no Brasil, (SAVIANI, 2011), entretanto, o acesso a educação de qualidade vai além do que a normatização demonstra, tendo em vista os casos de exclusão de uma parte da população na sociedade.

Com a aprovação da LDB foram revogadas as legislações educacionais anteriores tais como: lei 4.024/61 e 5.540/68, não alteradas pelas leis nos 9.131/95, e 9.192/95, e, ainda, as leis $\mathrm{n}^{\mathrm{0}} 5.692 / 71$, e 7.044/82, e as demais leis e decretos-lei que as modificaram e quaisquer outras disposições em contrário.

Para Saviani (2011) uma das inovações acerca dessa lei, está na educação básica: "formar indivíduos plenamente desenvolvidos em condições de assumir a direção da sociedade ou de controlar quem dirige", estipulando uma escola unificada pela inserção da educação infantil nessa categoria, conforme demonstrado nos artigos de 29 a 31 da LDB, os quais dissertam que a educação infantil, é a primeira etapa de ensino com a função de desenvolver a criança até seis anos de idade, em seu aspecto físico, psicológico, intelectual e social, por meio de creches e pré-escolas, sob o caráter avaliativo e acompanhando o desenvolvimento da criança.

Além da LDB e das normatizações ordinárias, existe também outra norma orientadora denominada de Parâmetros Curriculares Nacionais que objetiva orientar a educação e os demais componentes curriculares previstos pela lei maior da educação. A função dos PCNs é nortear os procedimentos educacionais levando em conta o espírito da lei e as características nacionais, regionais e locais.

Rodrigues (2002, p. 139) entende que a educação básica está direcionada na formação de indivíduos autônomos por meio da capacitação das "competências humanas da comunicação (linguagem), da interação social e da competência objetiva (trabalho)".

Embora essas diretrizes delimitem conteúdos e objetivos que alcancem uma formação ampla do indivíduo e uma superação da realidade social, Rodrigues verifica que os organismos sociais ainda estão ligados a vertentes ideológicas voltadas a uma cidadania neoliberal e aos interesses do modelo social capitalista, tendo em conta a capacitação da 


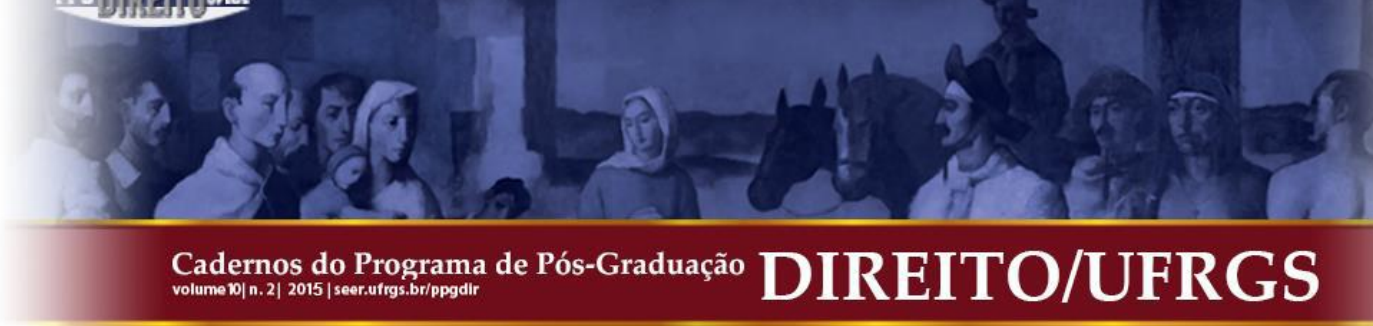

"autonomia, múltiplas habilidades, policognição, polivalência, formação abstrata, capacidades e competências ligadas a flexibilidade, participação, trabalho em equipe e competitividade" (RODRIGUES, 2002, p. 143).

\title{
2 EDUCAÇÃO E DIREITO
}

\subsection{Natureza Jurídica da Educação}

Primeiramente deve-se observar que a educação é um bem fundamental a vida, e base no desenvolvimento da pessoa humana, a partir da concretude da cidadania e, assim instrumento na transformação social, segundo demonstra Saviani (2011, p. 1):

\begin{abstract}
Ora, a educação é inerente a sociedade humana, originando-se do mesmo processo que deu a origem ao homem. Desde que homem é homem ele vive em sociedade e se desenvolve pela mediação da educação. A humanidade se constituiu a partir do momento em que determinada espécie natural de seres vivos se destacou na natureza e, em lugar de sobreviver adaptando-se a ela necessitou, para continuar existindo, adaptar a natureza em si. Em consequência do fenômeno acima apontado, o homem tem de se apropriar da natureza e transformá-la de acordo com suas necessidades, sem o que ele perece. Para continuar existindo o homem necessita produzir sua própria existência. E a forma de sua existência é determinada pelo modo como e a produz ou, já que o homem só existe em sociedade, a forma da sociedade é determinada pelo modo como é produzida a existência humana em seu conjunto.
\end{abstract}

Nesse sentido, para que haja a existência do ser humanos de forma digna, é necessária uma conjuntura de direitos, ou seja, os direitos fundamentais, direitos humanos, direitos de personalidade, direitos naturais, direitos do homem, direitos subjetivos públicos, liberdades públicas, direitos individuais e liberdades fundamentais.

Silva (2005, p. 179), aduz que os direitos fundamentais são situações jurídicas, objetivas e subjetivas, definidas no direito, em prol da dignidade, igualdade e liberdade da pessoa humana.

Já o regime jurídico da educação, integra-se no Direito Público, e Carvalho (2011, p. 1280), observa-se que é o direito à educação um dos mais importantes direitos sociais, pois é essencial para o exercício de outros direitos fundamentais. E ainda é possível delimitar a educação como direito social público subjetivo, devendo ser concretizado nas políticas sociais, embasados nos fundamentos e princípios da Constituição Federal. 


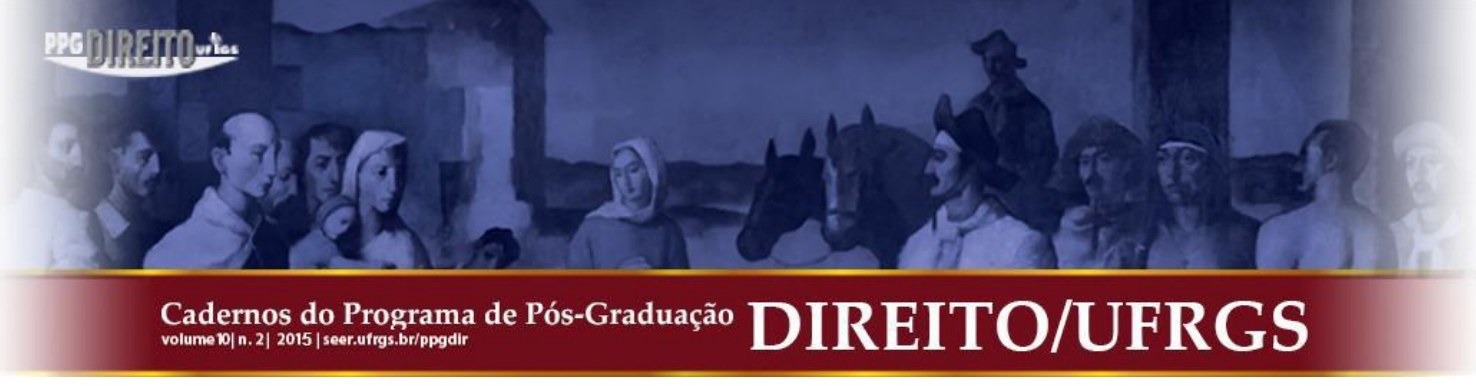

Portando, a educação é um dever do Estado nas políticas basilares, tendo em vista seu caráter social e público subjetivo da população, podendo executá-lo perante ao Poder Público na faculdade de exigir a relação jurídico-administrativa, caso haja a inexistência de seu cumprimento, garantidos por normas jurídicas.

\subsection{Remédios constitucionais}

É dever do Estado desenvolver as melhores formas de acessibilidade para a população acerca da educação, haja vista seu caráter social, público e subjetivo, sob pena da prestação jurisdicional garantida aos cidadãos. Nesse contexto Carvalho (2011. p. 791) demonstra:

A garantia da justiciabilidade dos direitos sociais passa necessariamente pela garantia da jurisdição, pelo qual o Estado tutela as pessoas em situação social vulnerável e cria condições para a redução das desigualdades. A negativa do Estado, sobretudo por opção do administrador público, em não cumprir a obrigação social de natureza e divisibilidade definidas, autoriza que o direito seja demandado junto ao Poder Judiciário para que ordene ao Estado a realização da atividade social.

A presente afirmação, é ratificada nos parágrafos do artigo 208 da Magna Carta Constitucional:

$\S 1^{\circ}$ : O acesso ao ensino obrigatório e gratuito é direito público subjetivo.

$\S 2^{\circ}$ : O não oferecimento do ensino obrigatório pelo poder público, ou sua oferta irregular, importa responsabilidade da autoridade competente.

Nesse sentido, o parágrafo segundo demonstra a possibilidade de requerer a prestação jurisdicional perante o Poder Publico. Assim, deve-se atentar aos remédios constitucionais cabíveis no amparo jurídico ao direto educacional, dentre eles o mandado de segurança e o mandado de segurança coletivo.

A Constituição Federal de 1988 define o mandado de segurança, no artigo 5², LXIX:

Art. $5^{\circ}$ - ...Todos são iguais perante a lei, sem distinção de qualquer natureza, garantindo-se aos brasileiros e aos estrangeiros residentes no País a inviolabilidade do direito à vida, à liberdade, à igualdade, à segurança e à propriedade, nos termos seguintes:

LXIX - conceder-se-á mandado de segurança para proteger direito líquido e certo, não amparado por "habeas corpus" ou "habeas data", quando o responsável pela ilegalidade ou abuso de poder for autoridade pública ou agente de pessoa jurídica no exercício de atribuições do Poder Público. 


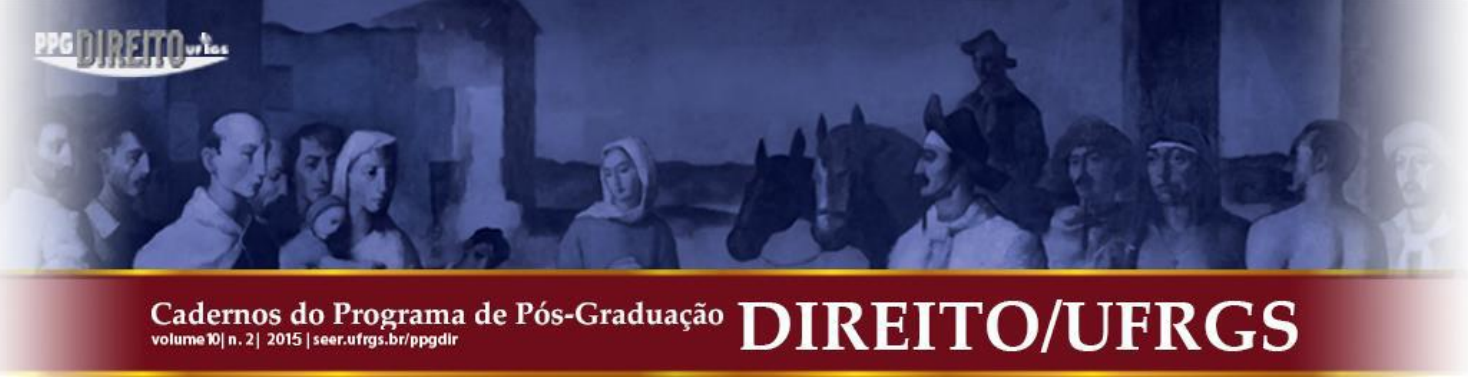

E em face ao mandado de segurança coletivo, a Constituição Federal preceitua no artigo $5^{\circ}$, LXX:

o mandado de segurança coletivo pode ser impetrado por: a) partido político com representação no Congresso Nacional; b) organização sindical, entidade de classe ou associação legalmente constituída e em funcionamento há pelo menos um ano, em defesa dos interesses de seus membros ou associados.

Assim, verifica-se que o mandado de segurança é um meio constitucional colocado a disposição de toda pessoa física, jurídica e órgão com capacidade processual ou universalidade reconhecida em lei, para a proteção de direito individual ou coletivo, líquido e certo, não amparado por habeas data e habeas corpus, lesado ou ameaçado de lesão por autoridade seja elas quais forem.

Já o mandado de segurança coletivo, com base nos artigos 21 e 22 da Lei 12.016/2009, dispõe que o mandado de segurança coletivo pode ser impetrado por partido político com representação no Congresso Nacional, na defesa de interesses individuais e coletivos legítimos relativos a seus integrantes, em defesa de seus direitos líquidos e certos da totalidade, ou de parte, dos seus membros ou associações, na forma de seus estatutos e desde que pertinentes às suas finalidades, dispensando, para tanto, autorização especial.

Além do mandado de segurança, há o mandado de injunção, exposto em no artigo $5^{\circ}$, LXXI, CF "conceder-se-á mandado de injunção sempre que a falta de norma regulamentadora torne inviável o exercício dos direitos e liberdades constitucionais e das prerrogativas inerentes à nacionalidade, à soberania e à cidadania".

Conforme leciona Carvalho (2011, p. 779), o mandado de injunção visa possibilitar o exercício de direitos e liberdades constitucionais e de prerrogativas inerentes à nacionalidade, à soberania e à cidadania, inviabilizados pela falta de norma regulamentadora do dispositivo constitucional não autoaplicável que os instituiu.

\subsection{Educação e a Constituição Federal}

Na Magna Carta a educação é retratada especialmente nos artigos 205 a 214, ensejando-se forma detalhada na seção I "Da Educação", que está dentro do Capítulo III: "Da Educação, da Cultura e do Deporto" ratificando o direito a educação no artigo 205 "a educação, direito de todos e dever do Estado e da família, será promovida e incentivada com a 


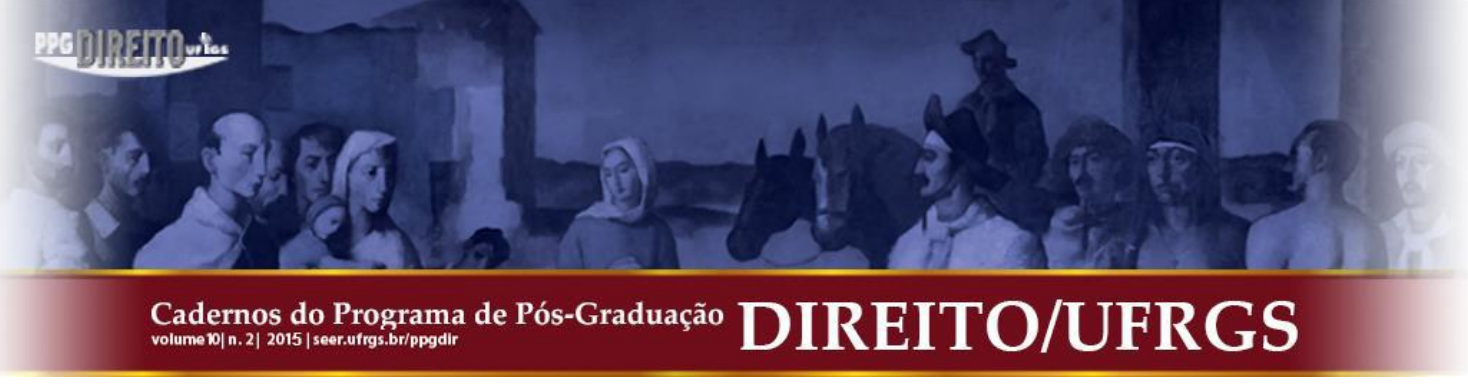

colaboração da sociedade, visando ao pleno desenvolvimento da pessoa, seu preparo para o exercício da cidadania e sua qualificação para o trabalho".

Alguns artigos em especial devem ser detalhados para melhor compreensão, dentre eles, há o artigo 206 o qual retrata os princípios basilares do ensino:

O ensino será ministrado com base nos seguintes princípios:

I. igualdade de condições para o acesso e permanência na escola;

II. liberdade de aprender, ensinar, pesquisar e divulgar o pensamento, a arte e o saber;

III. pluralismo de ideias e de concepções pedagógicas, e coexistência de instituições públicas e privadas de ensino;

IV. gratuidade do ensino público em estabelecimentos oficiais;

V. valorização dos profissionais da educação escolar, garantidos, na forma da lei, planos de carreira, com ingresso exclusivamente por concurso público de provas e títulos, aos das redes públicas;

VI. gestão democrática do ensino público, na forma da lei;

VII. garantia de padrão de qualidade;

VIII. piso salarial profissional nacional para os profissionais da educação escolar pública, nos termos de lei federal.

Motta (1997, p. 171 a 175) interpreta o inciso I em igualdade de condições na forma que ninguém poderá sofrer discriminações nas admissões e permanências na escola, tendo em vista que ninguém será excluído da escola, a não ser por motivo grave; no inciso II verifica-se a autonomia da escola e dos professores na liberdade de ensinar como princípio constitucional; o inciso III assegura a liberdade de escolha em relação à educação do educando deseja ou que a família quer dar aos seu filhos no ponto de vista político, ideológico e financeiro; o inciso IV retrata a gratuidade total nos estabelecimentos mantidos pelo Estado em todos os graus e todos estabelecimentos oficiais, quer federais, estaduais e municipais; o inciso V garante os planos de carreira, regime jurídico único nos estabelecimentos mantidos pela União, concurso público na entrada para o magistério público; inciso VI salienta acerca da democratização da administração escolar; inciso VII fala sobra a qualidade de ensino; VIII retrata sobre o piso salarial profissional.

O artigo 207 salienta acerca da autonomia da universidade de forma tríplice, ou seja, autonomia didático-científica; autonomia administrativa e autonomia de gestão financeira e patrimonial.

Já o artigo 208 enfatiza o dever do estado com a educação básica; ensino médio; atendimento educacional especializado aos portadores de deficiência; educação infantil creche e pré-escola; acesso aos níveis mais elevados do ensino, da pesquisa e da criação artística; ensino noturno regular, adequado às condições do educando; atendimento ao educando, em 


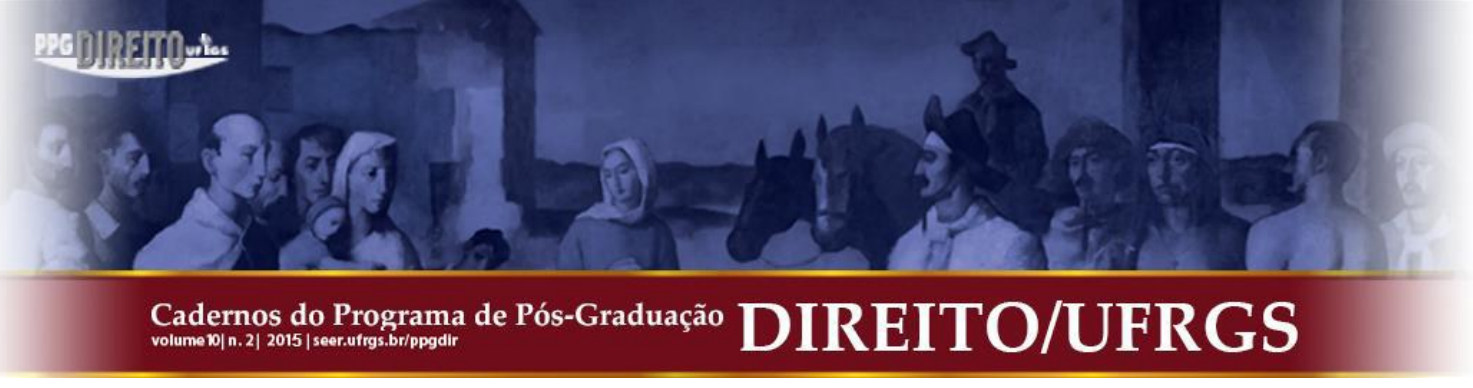

todas as etapas da educação básica, por meio de programas suplementares de material didático escolar, transporte, alimentação e assistência à saúde.

O artigo 209 demonstra que o ensino é livre à iniciativa privada, atendendo as normas gerais da educação nacional e a autorização e avaliação de qualidade pelo poder público.

O artigo 210, dispõe acerca do currículo e conteúdos mínimos:

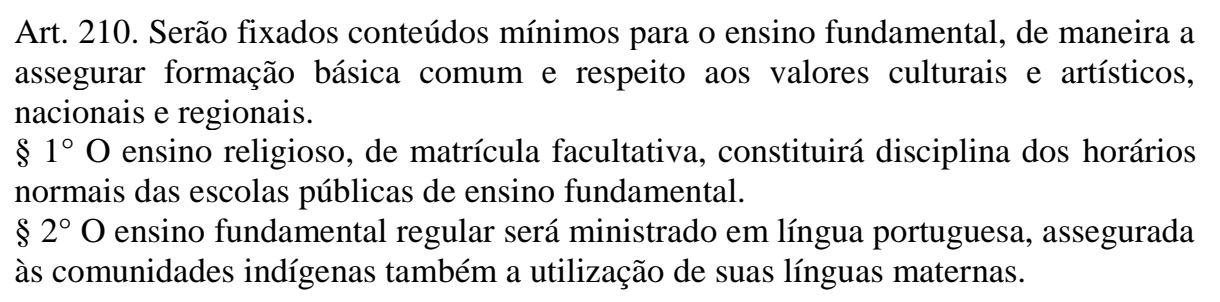

Já os artigos 211 a 214, relatam a organização do ensino; aplicação mínima financeira em educação, recursos públicos para escolas comunitárias, confessionais ou filantrópicas e o plano nacional de educação.

\section{EDUCAÇÃO/IDEOLOGIA/DIREITO}

Após a reforma educacional dos anos 1980 e 1990, percebe-se que atualmente existe um discurso idealizado acerca ao direito a educação universal, decorrente do processo de redemocratização conforme Constituição Federal de 1988 e a LDB, mas também pelo processo capitalista contemporâneo.

É pela condição formal normativa que o Estado de direito demonstra uma igualdade falseada entre os sujeitos na legislação. Por meio do ordenamento jurídico o Estado se apresenta como neutro, controla comportamentos, impõe valores e regula a própria pessoa.

$\mathrm{O}$ direito, em face das contradições sociais e sua falsa neutralidade, faz com que a jurisdição e suas várias imagens, realizam em si uma legitimidade na regulação, controle e coesão da sociedade em seu todo, ou seja, todos os sujeitos são iguais e universais perante a lei. Em sua aparência o mundo jurídico está completamente e por inteiro posto aí diante de nós, atual e potencialmente, como racional em si e por si, construído e construível plenamente pela práxis social consciente, como um objeto que se pode dominar totalmente ou quase totalmente pela vontade. (ALVES, 1987, p. 310).

Como se observa, estamos de frente ao caráter ideológico do Estado em face do processo de naturalização jurídica, de uma aparente redução imaginária das diferenças e 


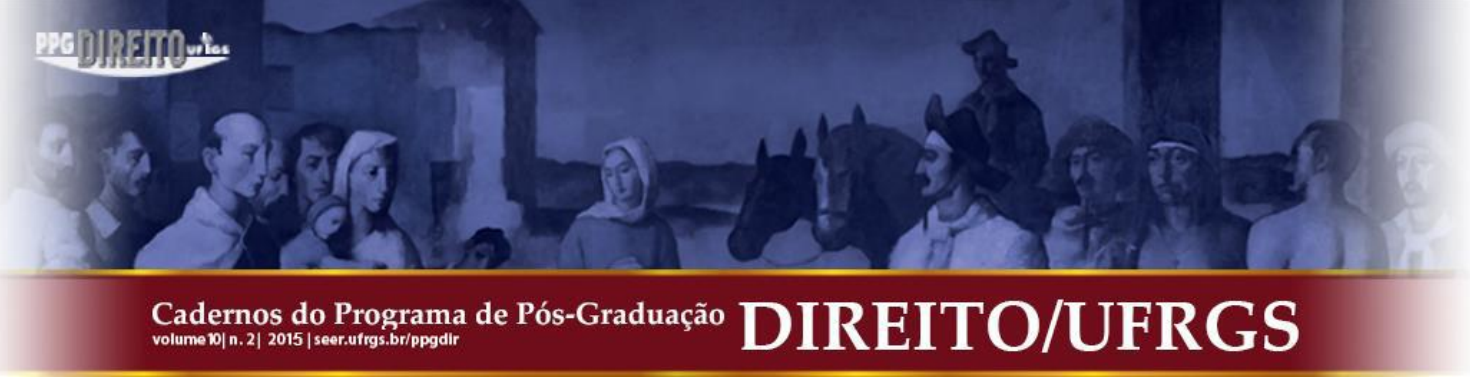

estruturação burocrática do Estado, da abstração da ação administrativa e dos procedimentos legais, buscando recriar o real por meio da instrumentalização social do saber e prática jurídica. Mesmo que exista essa diferenciação, o sujeito de direitos na ideologia realiza-se como possuidor da igualdade e liberdade de forma ampla e igual perante a lei. No entanto, deve-se atentar que é pela economia que há desigualdade social acerca da liberdade e igualdade, e que o Estado realimenta a dinâmica reprodução do capital.

As políticas educacionais são aparentemente concedidas em direitos na Constituição Federal, haja vista que as políticas sociais buscam a maior abrangência para os cidadãos. Nesse sentido Vieira (2001, p. 7), salienta que "as políticas sociais, apoiadas em direitos sociais, tornam-se obrigatórias e imediatas nas medidas estatais para elevar a condição humana dos titulares desse direito. Tais medidas vêm em resposta às necessidades sociais".

Entrementes, diante do exposto, Saviani (2008, p. 02) alerta que as políticas sociais:

decorre das características da sociedade capitalista cuja forma econômica se centra na propriedade privada dos meios de produção, o que implica a apropriação privada dos bens produzidos coletivamente. Com isso, a produção social da riqueza fica subordinada aos interesses privados da classe que detém o controle dos meios de produção.

É perceptível a propagação do capitalismo dentro do campo do direito e da educação visando que interesses de poucos, ou seja, uma ideologia da propriedade privada seja aceita de forma naturalizada por todos. Nesse sentido, é necessário fazer uma análise profunda perpassando as meras aparências cotidianas, conforme aduz Duarte (2008, p. 12):

\begin{abstract}
Quando uma ilusão desempenha um papel na reprodução ideológica de uma sociedade, ela não deve ser tratada como algo inofensivo ou de pouca importância por aqueles que busquem a superação dessa sociedade. Ao contrário, é preciso compreender qual o papel desempenhado por uma ilusão na reprodução ideológica de uma formação societária específica, pois isso nos ajudará a criarmos formas de intervenção coletiva e organizada na lógica objetiva dessa formação societária. [...] E qual seria a função ideológica desempenhada na assim chamada sociedade do conhecimento? No meu entender, seria justamente a de enfraquecer a luta por uma revolução que leve a uma superação radical do capitalismo, gerando a crença essa luta teria sido superada pela preocupação com outras questões "mais atuais", tais como a questão da ética na política e na vida cotidiana pela defesa dos direitos do cidadão e do consumidor, pela consciência ecológica, pelo respeito às diferenças sexuais, étnicas ou de qualquer outra natureza.
\end{abstract}

O Estado como ente repressor sempre delimitou a sociedade, tendo em vista que a hegemonia do poder da classe dominante (os ricos) deve prevalecer, nesse sentido Gramsci afirma que o Estado, “é um conjunto de órgãos da sociedade civil e política, qualquer que seja 


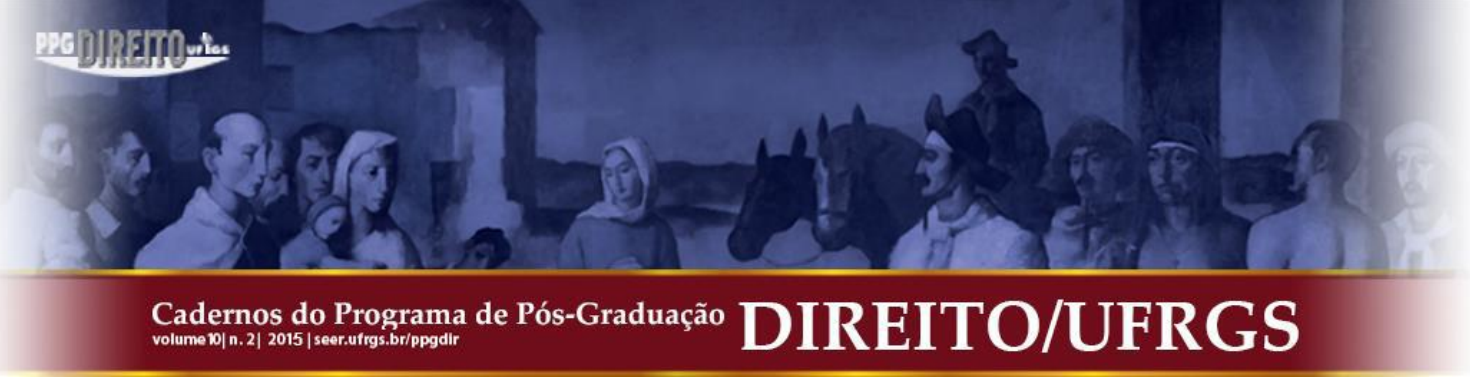

seu estatuto formal - organizações privadas ou aparelhos do estado - através dos quais é exercida a influência dominante." (LOWY, 2003, p. 28).

Assim, o estado faz relação de poder entre a sociedade civil e a sociedade política, inúmeras vezes o poder estatal modifica a sociedade e concomitantemente a o modo de vida da população. Observando-se o modo como a classe dominante usa a lei para delimitar a sociedade fazendo com que o legal apareça para o homem como legítimo, isto, é como justo e bom (ROCHA, 1991, p. 17).

A ideologia deve ser compreendida, a partir de alguns intelectuais, dentre eles Marx, Lenin e Gramsci. Marx denomina a ideologia como um conceito crítico que implica ilusão, ou se refere à consciência deformada da realidade que se dá por meio da ideologia dominante: as ideias das classes dominantes são ideologias dominantes da sociedade. Já Lenin, descreve a ideologia como qualquer concepção de realidade social e política, vinculada aos interesses das classes sociais. E ainda, a ideologia para Gramsci a ideologia é identificada como distinta da estrutura e se afirma que não são as ideologias que mudam a estrutura, mas, ao contrário, é a estrutura que muda as ideologias (LOWY, 2003, p. 12).

Ainda nessa seara Para Marx, em a Ideologia Alemã, (1998, p. 56) a concepção de ideologia está situada no âmbito da superestrutura, sendo denominada, sobretudo, como falsa consciência da realidade, como um conceito pejorativo, uma forma de ilusão ou uma consciência distorcida da realidade, disseminada pela classe dominante, sob a forma de ideologia dominante para todos. Para ele, a ideologia representa um conjunto de ideias que procuram ocultar a própria origem dos interesses sociais de um grupo particular da sociedade. Sob a forma de ilusão e/ou falsa consciência, a realidade passa a ser ocultada de suas contradições fundamentais e dos conflitos de classes. É nesse sentido que se pode afirmar que as ideias da classe dominante passam a constituir o pensamento dominante sobre as demais classes e o modo de pensar da sociedade de forma geral.

A partir do conceito de ideologia referido por Marx, é necessário refletir o que está implícito e explícito no direito à educação demonstrado na Carta Magna.

Nesse sentido, a Constituição Federal traz em seu texto o artigo $5^{\circ}$, salientando "todos são iguais perante a lei sem distinção de qualquer natureza" e no artigo $6^{\circ}$ "São direitos sociais a educação, a saúde, a alimentação, o trabalho, a moradia, o lazer, a segurança, a previdência social, a proteção à maternidade e à infância, a assistência aos desamparados, na forma desta Constituição". 


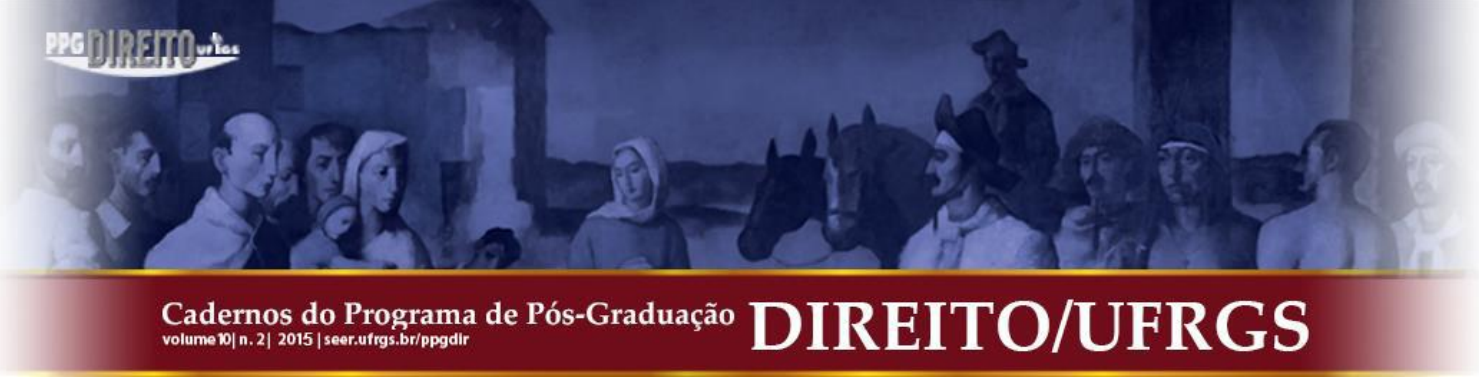

Silva, demonstra a importância dos direitos sociais, tendo em vista que "valem como pressupostos do gozo dos direitos individuais na medida em que criam co condições materiais mais propicias ao aferimento da igualdade real, o que, por sua vez, proporciona condição mais compatível com o exercício efetivo da liberdade".

E ainda (CARVALHO, 2011, p. 629) detalha:

\begin{abstract}
São direitos de status positivus, já que permitem ao indivíduo exigir determinada atuação do Estado, com o objetivo de melhorar as condições de vida, garantindo os pressupostos materiais para o exercício da liberdade. Envolvem a melhoria de vida vastas categorias da população, mediante a instituição de execução de políticas públicas.
\end{abstract}

Nesse contexto, percebe que a educação é um direito subjetivo e ao mesmo tempo um direito social, ou seja, universal, o qual é dever do Estado prover. Motta (1997, p. 166), enseja que o "direito à educação evoluiu em nossas Constituições em nossas Constituições e em nossas leis e já não é mais um direito puramente abstrato, mas um direito público subjetivo que tem plena eficácia”.

Entretanto, deve atentar-se que a educação não é prioritária na atuação dos governos, tendo em vista, a situação da educação infantil, ensino médio e a educação superior, a falta de escola, estrutura e materiais didáticos para todos, o descaso com a formação docente:

[...] não podemos deixar de destacar que "Educação" é uma necessidade humana produzida a partir da própria ação dos seres humanos para a transformação do real. Ela é, portanto, parte fundamental da história humana, uma vez que é a partir dos seus pressupostos que podemos problematizar acerca das matrizes que legitimam a luta de classes. Assim, toda leitura educacional que não esteja vinculada ao projeto histórico de transformação das condições materiais e objetivas da realidade se tornam fonte de crítica do próprio pensamento educacional. É nesse momento, também, que podemos analisar as relações de causa e efeito entre o produto da pesquisa e a sua relação com a educação. Desse ponto de vista, o que se percebe hoje é justamente a falta de identificação entre a teoria e a prática: há um total descompasso entre atividade docente e as discussões sobre a educação propostas tanto em teses e dissertações como em revistas especializadas; há um profundo hiato entre o que se produz e a realidade escolar e são sobre essas condições que se apontam os fracassos da educação brasileira. (SILVA, 2010, p. 56)

Nesse contexto, Pacheco apud Motta (1997, p. 166) ratifica "a educação como direito de todos, num plano de igualdade e disseminação, não é um preceito para uma completa vigência". Afirmação essa confirmada por Gnerre (1994, p. 10):

Os cidadãos apesar de ser declarados iguais perante a lei, são na realidade, discriminados já na base do mesmo código em que a lei é regida. A maioria dos 


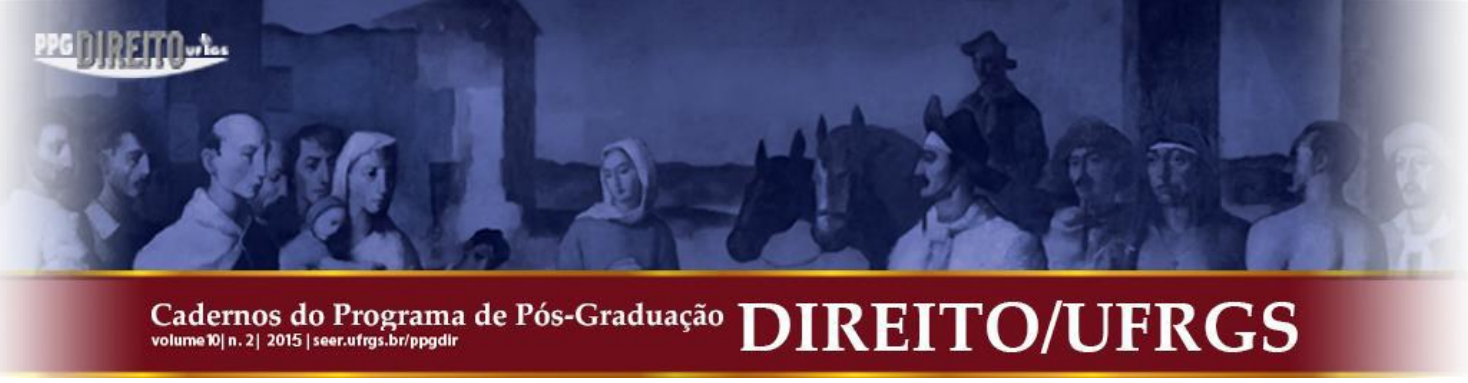

este Estado dentro da sociedade capitalista age em função da manutenção da ideologia dominante para que os valores e os interesses da burguesia sejam reproduzidos e mantidos. Porém, cabe lembrar que Gramsci, ao mesmo tempo critica o poder coercitivo e repressivo do estado, admite também que este é um importante espaço de lutas hegemônicas das classes excluídas e marginalizadas socialmente.

Ao analisar o direito, percebe-se que além de dissimular a justiça em nome da igualdade e liberdade, delimita os direitos e as obrigações nas relações sociais assegurando a cada um aquilo que lhe é devido por meio de instrumentos coercitivos e repressivos, naturalizando a injustiça instalada na base social.

A ideologia do sistema educacional, possui uma história com suas particularidades, sendo construída por particulares, mas colidindo com força social particular.

O Futuro da Educação incide, portanto, na análise aos fatores históricos que compõem as estruturas ideológicas e de manutenção da ordem vigente em que estamos inseridos. Infere-se desse fato, que são sobre as condições materiais que determinam o sentido da vida, que essa análise deve compor os nexos de sua crítica. Todavia, os problemas pelos quais se exprimem os sentidos da educação se desdobram na reflexão acerca do Presente. Embora saibamos que os sentidos dados à educação são perpassados pela questão das políticas educacionais, o espaço de reflexão sobre esse fato é ainda a realidade sócio/educativa. É nesse espaço de reflexão, que os atores da luta social devem se contrapor aos fatores ideológicos que determinam os objetivos da educação contemporânea, de modo especial aos paradigmas da concepção complexa. (SILVA, 2010. p. 248)

A partir dessa reflexão, considero que a busca em compreender a realidade de maneira particular acerca da relacional educação, ideologia e direito, percebe que aparentemente existe um discurso idealizado acerca do real. E a partir da sociedade capitalista, tal discurso é legitimado aos valores burgueses, valores estes que resultam efeitos na subjetividade, dignidade, cidadania e exclusão do indivíduo.

Nessa direção, a Constituição de 1988 e a edição da nova Lei de Diretrizes e Bases da Educação Nacional (1996), parece indicar este caminho defendendo a democratização do ensino, buscando constituir uma identidade pautada pela liberdade política e participação do povo, no entanto, contrariamente parece que se trata de uma concepção ideológica enquanto direito de todos, acesso a todos, permanência de todos no processo de forma qualitativa e igualitária, não passando, portanto de representações idealizadas do direito social.

Em síntese a Lei 9.394/96 pode ser considerada um marco simbólico de organização da educação brasileira, todavia apresenta traços da política neoliberal, que imprimiu certo tipo educação, com ênfase no mercado, na privatização e na redução do financiamento de políticas 


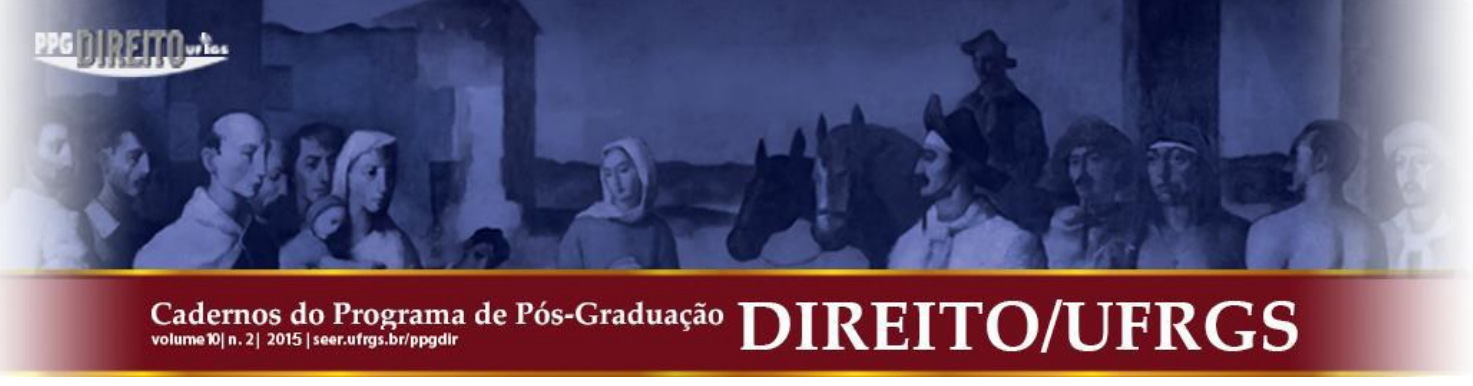

públicas por parte do Estado. Embora o objetivo seja de democratizar a educação, isto não se tornou possível pelos próprios limites do capitalismo no Estado neoliberal. Mas uma vez se constata o distanciamento entre o legal e o real na educação o que preconiza a lei e sua efetivação prática.

Se atentarmos que a finalidade da educação acerca da compreensão humana perpassa pela formação política da massa, entendemos que existe uma grande lacuna na realidade, haja vista a problematização que há na escola e seu papel educacional acerca da dominação dos valores burgueses.

Diante da complexidade das temáticas que envolveram a pesquisa, é certo de que se deve refletir e continuar a discussão sobre o modo como a legislação direciona o campo da educação e de como a ideologia dominante nos conforma enquanto sujeitos garantidores de um direito meramente formal, porém não real.

Portanto, cabe aos profissionais que lutam pelo direito social, encarar a legislação não como um simples discurso sem consequências práticas e sim como um instrumento que deve ser transformado e reconstruído, haja vista que a lei se aplica de forma repressiva, coercitiva e avaliativa, permeada ideologicamente por valores e princípios dominantes que direcionam, delimitam e regulam a autonomia para a manutenção do sistema capitalista.

Nesse sentido, os sujeitos, por meio de uma práxis revolucionária, devem lutar para transformar a sociedade e, assim, alcançar as necessidades reais para a humanização em face a crítica da ideologia burguesa no que se refere ao âmbito sócio educacional.

\section{REFERÊNCIAS}

ARROYO, Miguel Gaia. Currículo, território em disputa. Petrópolis: Vozes, 2011.

BARRETO, Elba Siqueira de Sá; MITRULIS, Eleny. Trajetória e desafios dos ciclos escolares no país. Estudos Avançados. n 15 (42), 2001.

BRASIL. Lei 12.016 de 07 de agosto de 2009. Disciplina o mandado de segurança individual e coletivo e dá outras providências. Diário Oficial da República Federativa do Brasil. Brasília, 10 ago. 2009.

BRASIL. Lei 4.024 de 20 de dezembro de 1961. Fixa as Diretrizes e Bases da Educação Nacional. Diário Oficial da República Federativa do Brasil. Brasília, 20 dez. 1961. 


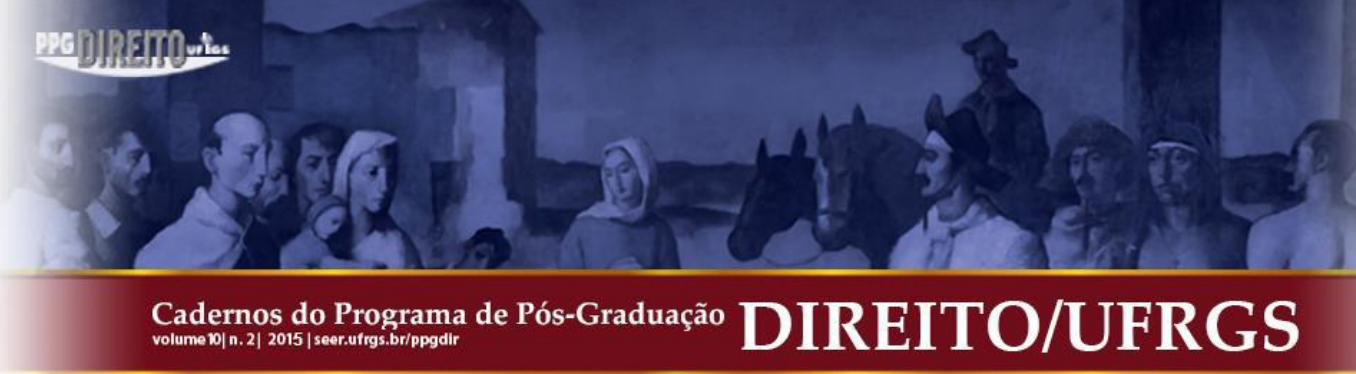

CARVALHO, Kildare Gonçalves. Direito Constitucional. Belo Horizonte: Del Rey, 2011.

DUARTE, Nilton. Sociedade do Conhecimento ou Sociedade das Ilusões? (Coleção Polêmicas do Nosso Tempo), Campinas - SP: Autores Associados, 2008.

FERNANDES, Claudia de Oliveira. A escolaridade em ciclos: práticas que conformam a escola dentro de uma nova lógica - a transição para a escola do século XXI. Tese de Doutorado. - Pós-graduação em Educação, PUC - Rio, Rio de Janeiro, 2003.

GNERRE, Maurício. Linguagem, escrita e poder. São Paulo: Martins Fontes, 1994.

HERMIDA, Jorge Fernando. A reforma educacional no Brasil (1988-2001): processos legislativos, projetos em conflito e sujeitos históricos. Paraíba: Universitária da UFPB, 2006.

LOWY, Michael. Ideologias e Ciência Social. Elementos para uma análise marxista. 16. ed. 218 São Paulo: Cortez, 2003.

MARX. Karl. A ideologia alemã/ Karl Marx e Friedrich Engels. São Paulo: Martins Fontes, 1998.

MOTTA, Elias de Oliveira. Direito Educacional e educação no século XXI: com comentários à nova Lei de Diretrizes e Bases da Educação Nacional. Brasília: Unesco, 1997.

NAGLE, Jorge. Educação e Sociedade na Primeira República. São Paulo, EPU; Rio de Janeiro, Fundação Nacional de Material Escolar, 1974. 1976, reimpressão.

NERY JUNIOR, Nelson. Constituição Federal comentada e legislação constitucional. São Paulo: Revista dos Tribunais, 2006.

RIBEIRO, Maria Luisa Santos. História da Educação Brasileira: A Organização Escolar. 20. ed. Campinas, SP: Autores Associados, 2007. - (Coleção Memória da Educação).

RODRIGUES, Anegleyce Teodoro. Gênese e sentido dos parâmetros curriculares nacionais e seus desdobramentos para a educação física escolar brasileira. Ciências do Esporte, Campinas, v. 23, n. 2, p. 135-147, jan. 2002 


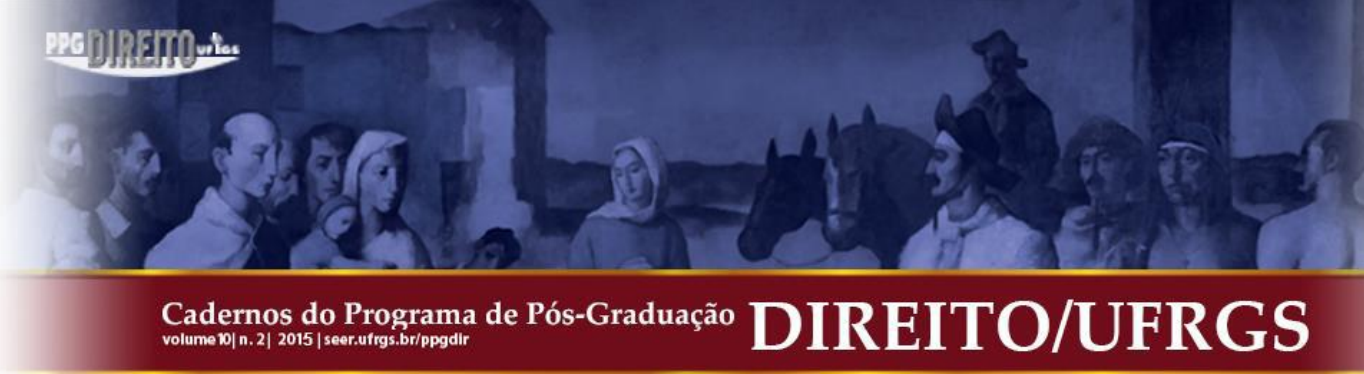

SAVIANI, Demerval. História das Ideias Pedagógicas no Brasil. Campinas: Autores e Associados, 2007.

Pedagogia no Brasil: História e Teoria. (coleção educação contemporânea) Campinas: Autores e Associados, 2008.

A nova lei da educação: trajetória, limites e perspectivas. 12. ed. Campinas: Autores Associados, 2011.

SILVA, Marcelo Donizete. Educação, ideologia e complexidade: contribuição para a crítica ao pensamento de Edgar Morin e sua interface com a educação brasileira. Universidade Estadual de Campinas. Doutorado em Educação. Faculdade de Educação. Campinas: 2010.

SILVA. José Afonso. Curso de Direito Constitucional Positivo. São Paulo: Malheiros Editores, 2006.

VASCONCELOS, Luzia Siqueira. Da Promoção em Massa à Progressão Continuada: o percurso da promoção escolar no Brasil. HISTEDBR. Disponível em: <http://www.histedbr.fae.unicamp.br/acer_histedbr/seminario/seminario7/TRABALHOS/L/L uzia\%20siqueira\%20vasconcelos.pdf >. Acesso em: set 2014.

VIEIRA. Evaldo. A política e as bases do direito educacional. Cadernos CEDES. Vol. $21 \mathrm{~N}$ 55. Campinas. 2001. <http://www.scielo.br/scielo.php?pid=S010132622001000300002\&script=sci_arttext $>$. Acesso em: 01 set 2014.

ZAIDAN. Samira. Reformas educacionais e formação de professores no Brasil. In: OLIVEIRA, Dalila Andrade (Org). Reformas educacionais na America Latina e os trabalhadores docentes. Belo Horizonte: Autêntica, 2003.

Submissão: 29/03/2015

Aceito para Publicação: 10/06/2015 
